\title{
O SETOR DE SEGURANÇA PRIVADA DA REGIÃO METROPOLITANA DE SÃO PAULO: crescimento, dimensões e características
}

\author{
Cleber da Silva Lopes*
}

\begin{abstract}
$\mathrm{O}$ artigo mobiliza o conceito ampliado de policiamento atualmente em voga na literatura internacional para mapear os tipos de atores ativos na provisão de segurança no Brasil e para analisar empiricamente as dimensões, o crescimento e algumas das características do policiamento executado pelo setor legal de segurança privada na Região Metropolitana de São Paulo. A análise empírica mostra que esse setor passou por um crescimento muito acelerado durante a década de 90, superando as forças de segurança pública em termos de efetivo, na década seguinte. A maioria dos seguranças particulares atua em espaços de trabalho, moradia, compras ou lazer onde a população passa grande parte do seu tempo. Assim, o cidadão médio encontra-se hoje mais exposto ao policiamento executado por agentes de segurança privada do que ao policiamento realizado por policiais da força pública. Esses fatos são discutidos à luz de uma agenda de pesquisa que ainda não se impôs nas ciências sociais brasileiras.

PALAvRAS-CHAvE: Controle social. Policiamento. Polícia. Segurança privada. Região Metropolitana de São Paulo.
\end{abstract}

\section{INTRODUÇÃO}

O sistema de controle social das sociedades contemporâneas tem sido marcado pela transferência das responsabilidades de policiamento do Estado para a sociedade. Esse fenômeno tem sido objeto de grandes debates acadêmicos entre criminólogos e estudiosos do policiamento de origem anglo-saxã. No centro dos debates em curso estão as empresas e profissionais de segurança privada. O setor de segurança privada constitui a face mais formal e visível do conjunto de atores não estatais atualmente engajados em atividades de policiamento. Não por acaso, esse setor foi o que mais recebeu atenção da literatura especializada de língua inglesa, que avançou significativamente nas últimas décadas no sentido de esclarecer as dimensões da segurança privada, sua expansão e características. Em contraste com a literatura inter-

* Doutor em Ciência Política. Professor Adjunto do Departamento de Ciências Sociais da Universidade Estadual de Londrina (UEL).

Rodovia Celso Garcia Cid (PR 445), km 380. Campus Perobal Cep: 86051-990. Londrina - Paraná - Brasil. Caixa-postal: 6001. cleber1lopes@hotmail.com nacional, pouco esforço teórico e empírico foi feito pela bibliografia nacional para compreender esse fenômeno dentro da realidade brasileira. Num estágio incipiente de produção, a literatura nacional carece tanto de estudos que levem em conta as questões teórico-conceituais presentes no campo dos policing studies, quanto de análises empíricas voltadas para identificar, dimensionar e caracterizar o setor de segurança privada no Brasil.

Este artigo procura suprir algumas dessas lacunas. Ele tem três objetivos inter-relacionados. No plano teórico, procura explicitar um quadro analítico que incorpore os desenvolvimentos conceituais presentes na literatura internacional e que, ao mesmo tempo, contribua para a identificação e análise das formas de policiamento existentes no Brasil. No plano metodológico, o artigo propõe procedimentos úteis para delimitar de forma acurada o setor legal de segurança privada dentro das bases públicas de dados. Por fim, no plano empírico, o trabalho apresenta um diagnóstico das dimensões, do crescimento e de algumas das características do setor legal de segurança privada da Região Metropolitana de São Paulo (RMSP), que é 
o maior e mais importante centro urbano do país. O artigo está organizado em duas partes e considerações finais. A primeira parte apresenta a tipologia das formas de policiamento de Muniz e Paes-Machado (2010), buscando torná-la mais explícita e inserida nos debates atualmente em curso no campo dos policing studies. A tipologia explorada nessa parte permite identificar claramente o setor de segurança privada dentro da estrutura de policiamento existente na sociedade brasileira, fornecendo, assim, o recorte teórico necessário à análise empírica desenvolvida na segunda parte do trabalho. Essa parte expõe os procedimentos utilizados para mensurar o setor legal de segurança privada algo que raramente ocorre nos trabalhos que abordam o fenômeno - e apresenta informações sobre as dimensões, o crescimento e as características desse setor na grande São Paulo. O artigo termina com a apresentação de uma breve agenda de pesquisa sobre o tema.

\section{ACERTANDO CONTAS COM A TEORIA}

\section{Descobertas empíricas e desenvolvimentos te- óricos no campo dos Policing Studies}

O campo dos estudos sobre o policiamento (policing studies) nasceu nos EUA, na segunda metade dos anos 60, focado em pesquisas sobre a polícia e suas práticas (Maning, 2005, p.1960). ${ }^{1}$

1 Apesar do foco na polícia, nunca houve um consenso em torno do seu conceito. Autores como Bayley (2001) propuseram uma definição ampla de polícia, que contempla organizações públicas e privadas, especializadas e não especializadas, profissionais e não profissionais. Outros, como Monjardet (2003) e Monet (2001), propuseram definições mais restritas. O primeiro definiu a polícia como a "força pública” especializada que expressa e cristaliza as reivindicações permanentes das comunidades políticas - não apenas da comunidade estatal em deter em seu território o monopólio do uso legítimo da força. Nessa mesma linha, Monet define a polícia como: 1) um tipo de ação coletiva organizada cujo recurso essencial é a força; 2) um tipo particular de organização estatal burocrática que se inspira na pirâmide das organizações militares e no recorte funcional das administrações públicas; e 3) um tipo de instituição singular em razão da posição central que ocupa no funcionamento de uma comunidade política. Amplas ou restritivas, essas definições são tributárias das formulações de Bittner, que, inspirado na sociologia weberiana, caracterizou a polícia "como um mecanismo de distribuição da
Os primeiros estudos partiam do pressuposto de que o policiamento é uma atividade cujo exercício legítimo é monopolizado pelo Estado, definido em termos weberiano como a associação humana cujo governo detém o monopólio da coação física legítima dentro dos limites de determinado território (Weber, 1999, p.525-529). ${ }^{2}$ Guiadas por essa visão, as pesquisas sobre policiamento privilegiaram inicialmente o estudo da natureza e do grau de autoridade efetivamente exercida pelos policias, que, na feliz expressão de Muir Jr. (1977), agem como "políticos de rua”, com enorme poder de interferência sobre os direitos civis cultivados nas democracias liberais. Embora o policiamento jamais tenha sido um monopólio da polícia no sentido econômico do termo (Jones; Newburn, 2002; Shearing, 2003), a influência da sociologia weberiana nesse campo de estudos acabou promovendo uma identificação entre polícia e policiamento. Essa identificação prevaleceu nos anos 50 e 60 e foi partilhada por pesquisadores nos dois extremos da arena política. Como Shearing (2003, p.436) observou, enquanto acadêmicos marxistas faziam críticas às alegações de que o Estado usava seu acesso à força para promover um bem geral, eles partilhavam da visão liberal segundo qual o policiamento é um monopólio do Estado.

Descobertas e desenvolvimentos teóricos ocorridos nas últimas décadas contrariaram essa visão arraigada acerca do policiamento e impeliram cientistas sociais e criminólogos de origem anglo-saxã a mudar o foco de suas pesquisas da polícia para os processos por meio dos quais indi-

força coercitiva não negociável empregada de acordo com os preceitos de uma compreensão intuitiva das exigências da situação" (Bittner, 2003, p.138). Na definição de polícia, esse trabalho alinha-se com as definiçõ̉es de Monjardet e Monet.

Isso não implica afirmar que os Estados sempre consigam efetivamente monopolizar o uso legítimo da força. A realidade do monopólio e a extensão de sua legitimidade são questões de fato que devem ser avaliadas empiricamente, caso a caso. Nesse sentido, nem as forcas armadas e nem a polícia podem, a priori, ser definidas como a expressão e a realização do monopólio estatal da violência legítima. Todavia, como notou Monjardet (2003, p.13-14), “[...] a inspiração weberiana permanece essencial para compreender a polícia [e as forças armadas] como expressão, e como instrumento, da reivindicação permanente inerente às comunidades políticas - e não só a comunidade estatal - de deter em seu território o monopólio dos empregos legítimos da força”. 
víduos e agências - diretamente ou por meio da designação de outros - provêm segurança e mantêm a ordem dentro de uma comunidade (Kempa; Stenning; Wood, 2004, p. 564). Essa mudança de perspectiva e os conceitos subjacentes a ela foi e tem sido objeto de um intenso debate acadêmico. Um dos principais deflagradores desse debate foi justamente a expansão, amplamente documentada em diversos países a partir dos anos 70, do que foi chamado de "segurança privada": empresas que vendem no mercado serviços e (ou) equipamentos de proteção (private security companies) e organizações que constituem departamentos de segurança que agem internamente (private security in house) (Shearing; Stenning, 1981). Outro fenômeno que impulsionou esse debate foi a emergência de atividades voluntárias de prevenção ao crime, a exemplo das iniciativas de autodefesa promovidas por cidadãos que patrulham ruas, neighborhood watch, associações de prevenção ao crime e grupos de caça a criminosos (Bayley; Shearing, 1996). Diante dessas mudanças, os estudiosos notaram que a sociedade, por meio do setor de segurança privada e de iniciativas comunitárias para prevenir e deter o crime, estava cada vez mais se envolvendo em atividades anteriormente reivindicadas com exclusividade pela polícia. A percepção era a de que a "polícia”, um certo tipo de instituição social organizada pelo Estado, e o "policiamento", uma conjunto de processos com funções sociais específicas, estavam crescentemente se tornando distintos e que novos conceitos deveriam ser formulados.

Vários pesquisadores romperam, então, com a tendência de identificar o policiamento com a polícia estatal (Johnston, 1992, 1999; Shearing, 1992; Bayley; Shearing, 1996, 2001; Kempa et al., 1999; Loader, 2000; Reiner, 2002; Jones; Newburn, 2006; dentre outros). Com essa ruptura, o policiamento deixou de ser entendido como a atividade desempenhada pela polícia e passou a ser analisado como um conjunto de processos instrumentais e específicos de controle social que podem ser executados por uma gama diversificada de atores e técnicas, sendo a ideia moderna de polícia apenas uma delas. Reiner (2004, p.19-22) foi quem melhor resumiu o conceito de policiamento atualmente em voga na literatura. Segundo ele, o policiamento diz respeito às tentativas para manter a segurança de uma ordem social particular ou da ordem social geral por meio de vigilância e ameaça ou uso de sanções. A ordem em questão pode estar baseada no consenso, no conflito e na opressão, ou ainda no entrelaçamento de ambos, que é geralmente o que ocorre nas sociedades complexas.

Nessa nova formulação, o policiamento não se resume às atividades realizadas pela polícia estatal, mas também não inclui todas as atividades de pessoas ou instituições que indiretamente contribuem para a promoção de segurança e manutenção da ordem. Policiamento não é sinônimo de controle social. ${ }^{3}$ Sociedades criam ordem e, consequentemente, esperam obter segurança por meio de processos de socialização e de disciplina informal que envolvem uma variedade de instituições e pessoas - cônjuges, pais, vizinhos, igrejas, escolas, empregadores, sindicatos, e muitos outros atores com alguma autoridade latente. Ocorre que essas pessoas e instituições não se dedicam explicitamente à promoção da segurança por meio de vigilância e ameaça de sanção. Por isso, suas atividades não podem ser caracterizadas como policiamento. Segundo Reiner (2004, p.22), policiamento diz respeito apenas às tentativas intencionais para promover a segurança na sociedade por meio da criação de sistemas de vigilância associados à ameaça ou ao uso de sanções em relação aos desvios descobertos. Nesse sentido, o policiamento é apenas um aspecto específico da noção mais ampla de controle social.

O entendimento ampliado do que vem a ser policiamento abriu uma nova linha de pesquisa dentro da área disciplinar compreendida pelos policing studies, que vem sendo chamada de "tendências do policiamento" ou "transformações do

${ }^{3}$ Controle social é uma noção complexa e muito debatida nas ciências sociais. Segundo a definição clássica de Cohen, controle social refere-se à "[...] maneira organizada com que a sociedade reage a pessoas e comportamentos considerados desviantes, problemáticos, ameaçadores, perturbadores ou indesejados.” (Cohen, 1985, p.1-2). 
policiamento". ${ }^{4}$ Como observou Kempa, Stenning e Wood (2004), essa linha de pesquisa tem prosperado em três frentes. Uma parte dos estudos tem se preocupado em identificar, caracterizar, dimensionar e explicar o crescimento dos atores não estatais que estão - e por longo tempo estiveram - ativos nos processos de policiamento (Jones; Newburn, 1998, 2002; Kempa et al. 1999; Bayley; Shearing, 2001; dentre outros). Uma segunda frente tem procurado analisar as semelhanças e diferenças entre os vários provedores de policiamento em termos de mentalidades, tecnologias, recursos e estrutura institucional mobilizada (Wood; Dupont, 2006). Por fim, esforços também estão sendo realizados para avaliar as implicações normativas que a fragmentação do policiamento traz para diferentes populações (Bayley; Shearing, 1996; Loader, 2000; Shearing; Wood, 2003a, 2003b).

Apesar da grande quantidade de trabalhos já produzidos dentro dessa nova linha de pesquisa, as investigações ainda são predominantemente exploratórias, e o progresso nas três frentes de estudos é bastante desigual. Os avanços mais notáveis ocorreram na primeira frente, com a maioria dos trabalhos empreendendo esforços para identificar, caracterizar e mensurar a magnitude das atividades de policiamento executadas pelo setor de segurança privada. O foco da literatura sobre esse setor é justificado. A última compilação de dados sobre as dimensões da segurança privada no mundo, realizada por Florquin (2011), revelou números surpreendentes. Em 31 dos 70 países para os quais o autor encontrou dados disponíveis, o setor de segurança privada empregava mais pessoas do que as forças policiais. Em termos absolutos, a soma do número de profissionais de segurança privada, nesses 70 países, era quase duas vezes maior do que a soma do número de policiais.

${ }^{4} \mathrm{O}$ rótulo "transformações do policiamento" também cobre análises sobre as mudancas que ocorrem dentro da esfera estatal, que, nas três últimas décadas, assistiu à emergência do policiamento comunitário, das parcerias público-privadas para a prevenção do crime, o avanço da mercadização (commodification) sobre o policiamento público, a expansão de corpos reguladores que desempenham funções policiais e o aumento do policiamento público transnacional e da cooperação entre agências policiais de diferentes países. Para uma resenha dessa literatura, ver Jones e Newburn (1998).
Apesar dos problemas metodológicos envolvidos na comparação do setor de segurança privada em nível mundial, os dados compilados por Florquin (2011) não deixam dúvidas quanto ao fato de que houve um intenso processo de pluralização do policiamento nas últimas décadas e que o setor de segurança privada é um dos principais atores dentro da estrutura de policiamento atualmente existente nas sociedades contemporâneas. Esse fenômeno também ocorreu na sociedade brasileira, cujo setor de segurança privada apresenta dimensões robustas (Lopes, 2011). Todavia os debates e as elaborações teóricas descritas anteriormente tiveram, até o momento, pouca repercussão na literatura nacional sobre violência, crime e segurança pública. Assim, antes de passar à apresentação das dimensões e características do setor de segurança privada na grande São Paulo, convém oferecer uma estrutura analítica que esteja ao mesmo tempo alinhada com os desenvolvimentos teóricos ocorridos no campo dos policing studies e que seja capaz de apreender as particularidades da realidade brasileira. Os primeiros passos nessa direção já foram dados, valendo a pena retomá-los.

\section{Uma tipologia das formas de policiamento}

De um modo geral, os estudos sobre controle social no Brasil têm permanecido imunes à ideia de que polícia e policiamento são conceitos distintos e que o sistema de controle social das sociedades contemporâneas tem sido marcado pela fragmentação ou pluralização das atividades de policiamento. A ausência de um arcabouço teórico-conceitual adequado para captar a realidade do policiamento plural parece ser uma das razões de os pesquisadores brasileiros terem se dedicado prioritariamente a analisar o policiamento realizado por agentes públicos, deixando em segundo plano o vasto e complexo conjunto de atores não estatais que estão ativamente engajados na promoção da segurança e manutenção da ordem dentro da sociedade brasileira.

Apesar da baixa assimilação pela literatura 
nacional dos desenvolvimentos teóricos descritos anteriormente, o conceito ampliado de policiamento foi mobilizado recentemente por alguns autores para pensar a realidade brasileira, caso de Wood e Cardia (2006), Muniz e Paes-Machado (2010) e Lopes (2011). ${ }^{5}$ Nas referidas obras, Wood e Cardia traçaram um esboço abrangente da estrutura de policiamento existente na sociedade brasileira, ao passo que Lopes ofereceu um panorama restrito às atividades de policiamento privado, tendo em vista a preocupação de analisar o alcance da regulação estatal sobre os provedores particulares de policiamento. Já Muniz e Paes-Machado deram uma contribuição importante do ponto de vista teórico, ao adotarem e defenderem o uso do conceito ampliado de policiamento numa agenda de pesquisa mais equilibrada e menos míope às atividades de policiamento privado. Visando a estimular estudos empíricos nessa direção, os autores propuseram uma tipologia interessante e que merece ser mais bem explicitada.

A tipologia sugerida por Muniz e Paes-Machado (2010) leva em conta três variáveis e seis atributos distribuídos ao longo de três continnum para enquadrar analiticamente os diferentes arranjos de policiamento que podem existir em sociedades complexas:

i) administração, governo: estatal ou não-estatal; ii) espaço, território: público ou privado; e iii) referência normativa: legal ou ilegal.

A variável referência normativa foi empregada por Muniz e Paes-Machado (2010) para distinguir as práticas de policiamento que ocorrem de acordo com o ordenamento jurídico em vigor (policiamento legal) daquelas que divergem de tal ordenamento (policiamento ilegal). Legalidade e ilegalidade são categorias situadas nas extremidades de um continnum que contém, em seu centro,

\footnotetext{
${ }^{5}$ Sintomático dessa baixa assimilação é o fato de o trabalho de Cardia e Wood ter sido produzido a partir de uma parceria entre uma autora brasileira (Nancy Cardia) e uma destacada pesquisadora anglo-saxã (Jennifer Wood), para uma coletânea publicada em língua inglesa, e o trabalho de Muniz e Paes-Machado ser o texto introdutório de um dossiê temático sobre policiamento que traz um único trabalho sobre formas não estatais de provisão de segurança, escrito por uma brasilianista (Martha Huggins) e publicado inicialmente num periódico americano (Huggins, 2000).
}

zonas de "alegalidade" formadas por práticas de policiamento que ocorrem sem que haja uma definição clara do Estado quanto à sua legalidade ou ilegalidade. ${ }^{6}$ Apesar de algumas modalidades de policiamento se desenvolverem em vácuos jurídicos, as categorias legal e ilegal são fundamentais na medida em que permitem captar as tensões que emergem em sociedades complexas e plurais entre legalidade e legitimidade. ${ }^{7}$ Como destacaram Muniz e Paes-Machado (2010), a partir dessas categorias é possível analisar, por exemplo, práticas ilegais de policiamento que são aceitas socialmente por certos grupos, ou ainda práticas legais que são desautorizadas ou deslegitimadas por alguns ou por todos. Nas palavras dos autores,

[...] ao se tomar o consentimento para policiar em suas dimensões legais e legítimas como uma chave problematizadora, abre-se a possibilidade de uma reflexão mais sensível acerca dos processos de construção da tolerância e dos níveis de aceitação dos indivíduos e grupos policiados em sociedades com Estado. Como resultado, podese avançar no entendimento da sutil fronteira entre obediência e sujeição e suas implicações sobre as formas de construção e exercício de autoridade e seus assentimentos (Muniz; Paes-Machado, 2010, p.443).

As variáveis administração e governo, e espaço e território também possuem grande relevância analítica, já tendo sido mobilizadas para a construção de uma matriz tipológica nos estudos de Davis et. al. (2000). Administração e governo é uma variável que indica a natureza pública ou privada dos agentes que executam policiamento. Mais especificamente, indica quem paga e controla as pessoas envolvidas em atividades de policiamento, ou seja, a quem os agentes de policiamento se subordinam no exercício de suas funções. O policia-

${ }^{6}$ Sobre essa zona de alegalidade em relação aos arranjos de policiamento privado, ver Lopes (2011, p.104).

${ }^{7}$ Legitimidade e legalidade são dois conceitos distintos. A legitimidade é um princípio que serve para diferenciar o poder de fato do poder de direito, isto é, para distinguir por exemplo, a violência praticada por um grupo de malfeitores da violência autorizada por determinado grupo social. Já a legalidade serve para diferenciar o bom e o mau governo; ela diferencia, no caso do uso da violência, um governo que utiliza a força física de maneira arbitrária de outro que a utiliza em conformidade com regras previamente estabelecidas (Bobbio, 2000, p.237). 
mento tem uma natureza pública e estatal quando os profissionais envolvidos em atividades policiais são pagos e administrados pelo Estado. Por outro lado, o policiamento é considerado privado ou não estatal quando é executado por agentes pagos e controlados por pessoas ou organizações pertencentes à esfera civil (não estatal). ${ }^{8} \mathrm{Em}$ algumas situações, nem sempre é possível fazer esse enquadramento de maneira inquestionável. Como já haviam alertado Shearing e Stenning (1981 p.196), entre o caráter claramente público dos policiais que trabalham nas organizações estatais e o caráter claramente privado dos agentes que trabalham em empresas de segurança, há toda uma área cinzenta composta por profissionais que desempenham funções de segurança em organizações semipúblicas (empresas de capital misto, por exemplo) e por policiais que utilizam o status, a autoridade e os recursos garantidos pela sua condição de agente público para realizar policiamento em nome de clientes privados. Por essa razão, a distinção entre agentes públicos e agentes privados também deve ser vista dentro de um continnum que comporta diferentes gradações de público ou estatal e privado ou não estatal. Enquadrar os atores que executam policiamento numa ou noutra categoria dependerá de avaliações empíricas acerca da natureza dos recursos recebidos e utilizados pelos agentes de policiamento e do grau de subordinação desses agentes às instituições ou pessoas a quem se vinculam.

${ }^{8}$ Remonta à antiguidade e foi transmitida através dos séculos a noção de que o "público" refere-se ao que é comunitário (coletivo), tendo como oposto o "privado", que diz respeito ao bem individual dos membros da comunidade. Sendo o governo a autoridade que age em nome da coletividade, a esfera pública é comumente identificada com o campo da ação governamental, ou melhor, das relações entre governantes e governados. Em oposição a isso, a esfera privada é definida como o campo das demais relações entre indivíduos e grupos sociais. Com a emergência do Estado enquanto unidade governamental soberana nos limites de um território, o pensamento político moderno passou a identificar o público com o estatal e o privado com o não-estatal. Nesse sentido, o policiamento seria público quando administrado pelo Estado, e privado quando governado por indivíduos ou organizações civis (não-estatais). $\mathrm{O}$ que distinguiria conceitualmente um policial de um agente de segurança privada seria, portanto, o fato deste último exercer suas atividades na condição de civil ou empregado de uma jurisdição não-estatal.
Por fim, a variável espaço e território indica se o policiamento ocorre num espaço pertencente à coletividade (espaço público) ou em espaços pertencentes a particulares (espaço privado). A divisão entre espaços pertencentes ao Estado, totalmente abertos ao público, e espaços privados, localizados em propriedades particulares de uso restrito, é menos nítida do que parece à primeira vista, sendo a ideia de um continnum novamente adequada para representar a existência de espaços que pertencem à esfera pública, mas que colocam restrições de acesso aos cidadãos (alguns tipos de repartições públicas, por exemplo), e de espaços localizados dentro do que Shearing e Stenning (1981) chamaram de "propriedades privadas de massa”: espaços privados que se parecem com espaços públicos na medida em que são áreas de uso coletivo habitadas ou frequentadas diariamente por grande quantidade de pessoas (condomínios residenciais, conjuntos de escritórios, parques industriais, shoppings centers, estádios de futebol, parques recreativos, etc)..$^{9}$ Apesar da existência desses "enclaves fortificados" (Caldeira, 2003), "espaços híbridos” (Kempa et al., 1999) ou "quase-públicos” (Button, 2003), a distinção entre espaço público, aberto e acessível a todo cidadão em virtude da sua condição de membro de um Estado-nação, e espaço privado, que mesmo quando aberto ao público, encontra-se sob o controle de um ou mais cidadãos que têm o direito de regular as condições de acesso e uso do espaço, preserva grande valor analítico em virtude das implicações que esses diferentes espaços e pressupostos têm sobre os mandatos e práticas de policiamento.

O cruzamento das três dimensões descritas acima resulta numa matriz de análise qualitativa de propriedades formada por quatro tipos puros de policiamento, que se subdividem, entre práticas legais e ilegais, em oito subtipos. A matriz tipológica proposta por Muniz e Paes-Machado (2010), com algumas modificações na sua forma de apresentação, pode ser vista na Ilustração 1. ${ }^{9}$ Para uma defesa da ideia de um continnum de espaços,
ver Kempa, Stenning e Wood (2004) e Jones e Newburn (1998). 


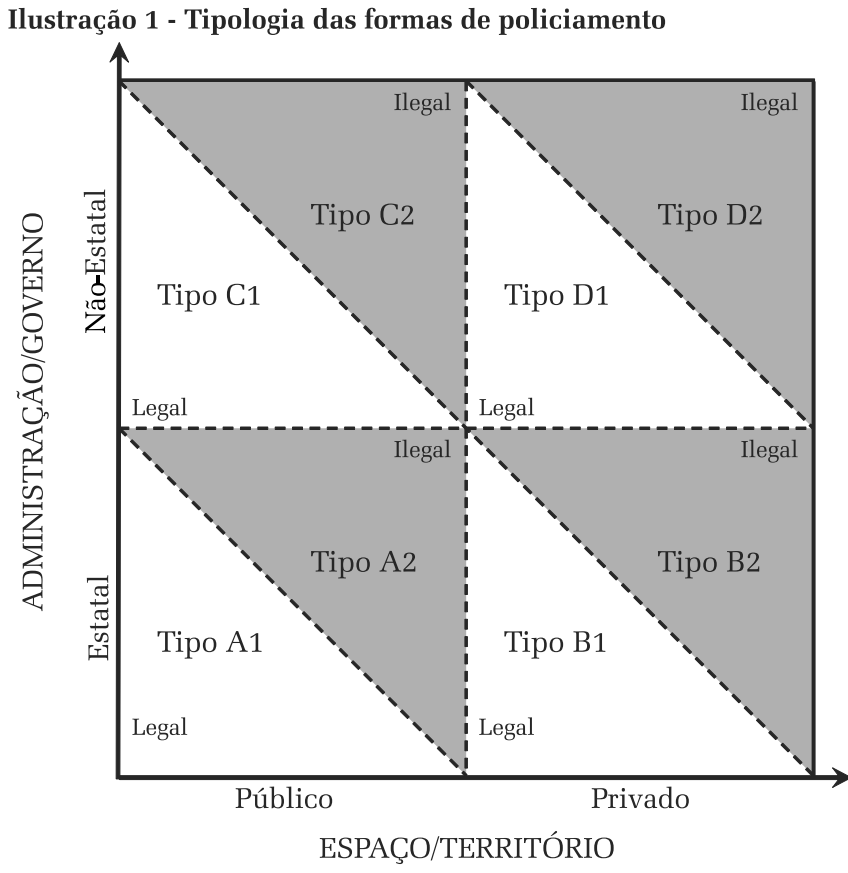

Fonte: Construído a partir de Muniz e Paes-Machado (2010)

O tipo A representa as práticas de policiamento público ou estatal que ocorrem em espaços públicos. Em sua forma mais pura, o subtipo A1 diz respeito ao policiamento convencional executado, com base num mandato legalmente estabelecido, por guardas municipais e por policiais militares, civis e federais em praças, parques e vias públicas. O subtipo A2 refere-se ao policiamento realizado ilegalmente por agentes estatais em espaços públicos. Inclui desde o policiamento vendido por policiais a moradores que desejam ou são extorquidos a pagar por serviços de vigilância, até formas violentas de policiamento praticadas por esquadrões da morte e milícias integradas por agentes de segurança pública. ${ }^{10}$

O tipo B abrange as práticas de policiamento levadas a cabo por agentes públicos em espaços privados. O subtipo B1 compreende o policiamento executado legalmente pelas forças de segurança públicas em locais como estádios de futebol e agências bancárias, por exemplo. Já o subtipo B2 indica o policiamento irregular praticado por agentes de segurança pública que aproveitam o seu horário de

${ }^{10}$ Sobre o subtipo A2 ver, por exemplo, os trabalhos de Costa (1998), Cano (2008), Huggins (2010) e Misse (2011). descanso para prestar serviços de vigilância patrimonial em condomínios residenciais, casas noturnas, postos de gasolina, supermercados e estabelecimentos comerciais em geral-o chamado bico policial.

Os tipos C e D compreendem as práticas de policiamento que menos receberam atenção da literatura brasileira. $\mathrm{O}$ tipo $\mathrm{C}$ circunscreve o policiamento realizado por agentes não estatais em espaços públicos. O subtipo $\mathrm{C} 1$ inclui as atividades de policiamento executadas por profissionais vinculados a empresas de segurança privada que possuem autorização legal para prestar serviços de vigilância patrimonial em áreas pertencentes ao Estado (parques públicos, terminais de transporte coletivo, repartições públicas, etc.) e serviços de transporte de valores, escolta de cargas e segurança pessoal de clientes VIPs que se deslocam nas vias públicas. O subtipo C2, por sua vez, abarca as práticas de policiamento desempenhadas ilegalmente por ligas comunitárias de autodefesa, guardas noturnas, agentes de segurança comunitária, vigias de rua, dentro outros atores não estatais que se dedicam à patrulha a pé, de bicicleta ou motorizada de ruas de bairros residenciais, muitas vezes iniciada sem a solicitação dos moradores, que posteriormente são impelidos ou achacados a pagar pelos serviços prestados. Também está incluso nesse subtipo o policiamento privado "neovigilante" de grupos de extermínio integrados por elementos nativos comprometidos com a eliminação de pessoas consideradas indesejáveis e com a pacificação, a qualquer custo, de seus locais de moradia e (ou) negócio. ${ }^{11}$

Por fim, o tipo D representa as práticas de policiamento executadas por agentes não estatais

${ }^{11} \mathrm{O}$ conhecido caso do justiceiro Esquerdinha é um exemplo típico dessa modalidade de policiamento em sua versão mais intolerante e violenta. Na segunda metade dos anos 80, Esquerdinha organizou, na região periférica de São Bernardo do Campo, uma organização policial clandestina (ROTA - Serviços de Segurança e Vigilância S/C LTDA), que cobrava pelos serviços prestados valores que variavam de acordo com a posse dos interessados. Essa organização, que chegou a contar com treze guardas e três viaturas, foi a responsável pela execução de inúmeras pessoas na região (Bicudo, 1988, p.113-119). 
dentro de espaços privados. Em sua dimensão legal (subtipo D1), refere-se às atividades de vigilância patrimonial intramuros, que são desempenhadas por profissionais ocupados em empresas de segurança que possuem autorização de funcionamento nos termos da Lei Federal $n^{\circ}$ 7.102/83 e demais normas que regulam a segurança privada no Brasil. Em sua dimensão ilegal (subtipo D2), as práticas de policiamento privado em espaços privados correspondem àquelas realizadas por agentes não estatais que não possuem a autorização do Estado para realizar a vigilância intramuros, configurando o que a Polícia Federal e o setor legal de segurança privada chamam de segurança privada clandestina.

A matriz analítica descrita apresentada acima, com seus tipos e subtipos, permite identificar as diversas práticas de policiamento presentes na sociedade brasileira, fornecendo, assim, subsídios teóricos para que floresçam estudos mais amplos e abrangentes do que os que têm dominado a literatura nacional sobre crime, violência e segurança pública. Como destacaram Muniz e PaesMachado (2010, p.442), a matriz também fornece recursos analíticos para explorar tipos híbridos de policiamento, caso do policiamento ilegal realizado em via pública por grupos de extermínio integrados por policiais e por civis, ${ }^{12}$ ou mesmo do policiamento legal que pode ser realizado em conjunto por policias e agentes de segurança privada dentro de grandes eventos. Para os propósitos deste artigo, a matriz é útil na medida em que permite localizar claramente as práticas de policiamento que são analisadas na sequência: o policiamento privado executado pelo setor legal de segurança privada, que, na matriz analítica exposta na Ilustração 1, é compreendido pelas siglas C1 e D1.

12 É o caso do grupo de extermínio que atuou em Itambé, Pernambuco, em 2002 e 2003, sob a fachada de uma empresa de segurança chamada Grupo de Proteção Comunitária (GPCOM). Formado por policiais e civis, o grupo foi acusado do extermínio de várias pessoas consideradas "almas sebosas". Para mais, ver Lopes (2007) e Huggins (2010).

\section{CONTRIBUINDO COM A EMPIRIA}

\section{Notas metodológicas e definições}

Os estudos voltados para apreender empiricamente o setor legal de segurança privada de diversas partes do mundo têm esbarrado em sérios problemas metodológicos. Legislações e bases de dados disponíveis em diferentes países adotam definições distintas sobre o que é segurança privada, dificultando análises comparativas e a mensuração precisa do setor. Para complicar ainda mais, dentro de uma mesma jurisdição, frequentemente há uma variedade de fontes de dados - censos governamentais, estatísticas oficiais sobre emprego, órgãos reguladores e estudos financiados pelas associações de classe - que utilizam critérios diferentes para mapear o setor.

Tal como é definida na legislação brasileira, a segurança privada é um setor de atividades que abrange três tipos de organizações:

i. Empresas de segurança privada especializadas: empresas de capital privado que possuem autorização do Ministério da Justiça ou da Polícia Federal para comercializar serviços de "vigilância patrimonial" intramuros, "transporte de valores", "escolta armada” e "segurança pessoal privada”. ii. empresas com segurança orgânica: empresas e organizações das mais variadas que estão autorizadas a executar serviços de "vigilância patrimonial" intramuros e "transporte de valores” para consumo próprio.

iii. cursos de formação de vigilantes: empresas de capital privado voltadas para a formação, especialização e reciclagem dos profissionais de segurança privada.

Os profissionais empregados pelas empresas especializadas e com segurança orgânica para a execução das atividades descritas acima são chamados de "vigilantes". Grosso modo, o segmento especializado e o orgânico correspondem àqueles que a legislação de diversos países trata pelo termo segurança privada. Grosso modo porque as leis de alguns países incluem, na definição, serviços de investigação particular e de segurança eletrôni- 
ca. No Brasil, esses serviços não fazem parte do universo legal da segurança privada.

O órgão público responsável pelo controle da segurança privada no Brasil é o Ministério da Justiça, que, desde 1995, executa essa tarefa por meio da Polícia Federal. Por essa razão, a Polícia Federal constitui a principal fonte de dados para a análise da evolução do número de empresas de segurança privada que atuam na RMSP. Os dados utilizados nessa análise foram extraídos do Sistema Nacional de Segurança e Vigilância Privada (SISVIP), que foi consultado em maio de 2011 por meio de demanda apresentada à Coordenação Geral de Controle de Segurança Privada (CGCSP), do Departamento de Polícia Federal (DPF). A análise baseou-se no número de empresas com autorização de funcionamento ativa no SISVIP no período entre 1990 e 2010. A contagem do número de empresas levou em consideração a movimentação de entrada de novas empresas no mercado e a movimentação de saída de empresas canceladas no período entre 01 de janeiro e 31 de dezembro de cada ano. Uma empresa foi considerada nova na situação em que ainda não havia obtido autorização de funcionamento para atuar na RMSP, e cancelada nas situações em que todas suas operações na região haviam sido encerradas perante a Polícia Federal. Para operacionalizar a contagem, foram consideradas as datas em que as portarias de autorização de funcionamento e as portarias de cancelamento foram publicadas no Diário Oficial da União (DOU). As datas das portarias de autorização e de cancelamento foram gentilmente cedidas pelo sindicato que representa as empresas de segurança do Estado de São Paulo (SESVESP) e por uma empresa que presta consultoria ao setor (Datasafe). Para os casos em que não foi possível localizar as informações sobre a data de publicação da portaria de cancelamento, utilizou-se a data de validade da última portaria de autorização de funcionamento.

Os dados utilizados para as séries históricas relativas ao número de vigilantes ocupados no setor de segurança privada não puderam ser obtidos via Polícia Federal, pois o SISVIP não permite consultas por ano. Assim, os dados anteriores a
2011 foram extraídos da Relação Anual de Informações Sociais (RAIS) do Ministério do Trabalho e Emprego (MTE), que, no momento da realização do trabalho, estava disponível até o ano de 2010. Por meio da RAIS, todo estabelecimento deve fornecer anualmente ao MTE informações referentes a cada um de seus empregados: ocupação exercida segundo a Classificação Brasileira de Ocupações (CBO), tipo de admissão, vínculo, causas de desligamentos, características individuais (idade, sexo, grau de instrução), etc. Também são fornecidas informações sobre os estabelecimentos: tipo de atividade que realiza conforme a Classificação Nacional de Atividades Econômicas (CNAE), localização geográfica, natureza jurídica, etc. Tendo como referência a CNAE e a CBO, é possível delimitar o setor de segurança privada e acompanhar a sua evolução nos últimos anos. Isso foi feito considerando-se os vínculos empregatícios ativos em 31/ 12 para o período de 2007 a 2010. Não foi possível extrair uma série histórica tão longa quanto a utilizada para a análise da evolução do número de empresas autorizadas, pois ocorreram mudanças, nas duas últimas décadas, no enquadramento do setor de segurança privada dentro da CNAE, descontinuando a série histórica. Por esse motivo, optou-se por analisar os dados somente a partir de 2007, ano seguinte ao último reposicionamento do setor de segurança privada dentro da CNAE.

Embora a RAIS seja uma fonte de dados adequada para analisar o número de vigilantes ocupados no setor de segurança privada, as informações extraídas dessa base de dados estão sujeitas a algumas distorções decorrentes do enquadramento impreciso do setor legal de segurança privada na CNAE e na CBO. O segmento especializado na prestação de serviços de segurança privada é atualmente englobado pelas categorias da CNAE mostradas no Quadro 1. Já o segmento orgânico é englobado por todas as demais categorias que não aparecem no Quadro 1.

Integram o segmento especializado na prestação de serviços de segurança privada apenas as atividades compreendidas pelas subclasses 80111/01 e 8012-9/00, assinaladas em cinza no Quadro 
Quadro 1 - CNAE 2.0 que inclui o setor de segurança privada

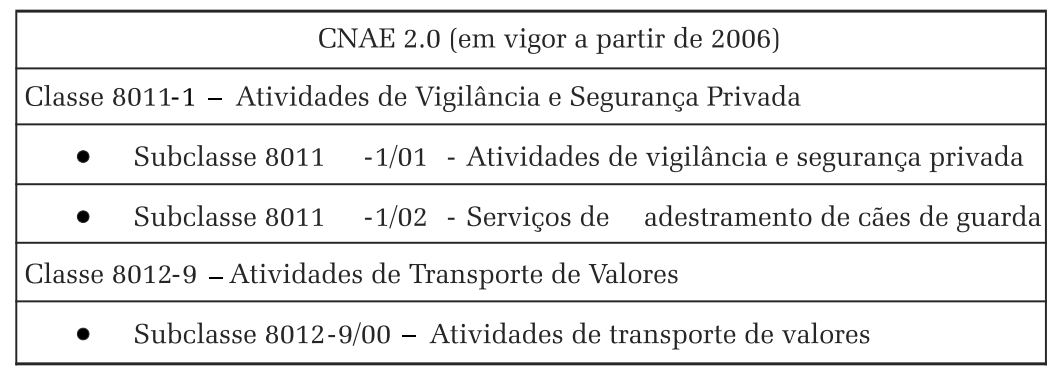

Fonte: CNAE 2.0

1. Embora as atividades de serviços de adestramento de cães de guarda não façam parte do segmento especializado, essa atividade não pode ser excluída da análise porque "classe" é o menor nível de desagregação possível da CNAE. Assim, qualquer análise sobre o segmento especializado na prestação de serviços de segurança privada será distorcida pelos serviços de adestramento de cães de guarda.

A CBO 2002 também coloca alguns problemas para a delimitação precisa do número de vigilantes regularmente empregados no setor de segurança privada. Uma comparação entre a descrição dos cargos previstos na Convenção Coletiva/
Dissídio Coletivo do SESVESP e a descrição das ocupações da CBO 2002 mostra que os profissionais de segurança privada integram duas famílias ocupacionais (ou grupos de base), conforme é apresentado no Quadro $2 .^{13}$

Os profissionais regulares de segurança privada estão enquadrados nas ocupações assinaladas em cinza no Quadro 2. Contudo um olhar mais atento para a descrição dessas ocupações revela que nem todas são típicas do setor regular de segurança privada. Ocupações como "guarda valores" e "segurança comunitária”, por exemplo, não fazem parte do universo legal da segurança privada. Como ocupação é o menor nível de desagregação possível da RAIS, foi necessário adotar filtros para minimizar as distorções decorrentes da agregação imprecisa da CBO. O procedimento adotado foi extrair os dados da RAIS levando em considera-

Quadro 2 - CBO 2002 que inclui os profissionais de segurança privada

Família Ocupacional 5173 - Vigilantes e guardas de segurança

- Ocupação 5173-05 - Agente de proteção de aeroporto: vigilante de aeroporto

- Ocupação 5173-10 - Agente de segurança: segurança comunitária, segurança de evento, segurança pessoal

- Ocupação 5173-15 - Agente de segurança penitenciária: agente penitenciário, carcereiro, chaveiro carcereiro, guarda de presídio, guarda penitenciário, inspetor de presídio

- Ocupação 5173-20 - Vigia florestal : guarda-rural, guarda-territorial, inspetor de guarda-territorial, mateiroguarda florestal

- Ocupação 5173-25 - Vigia portuário

- Ocupação 5173- 30 - Vigilante : agente de segurança ferroviária, assistente de segurança, auxiliar de segurança, auxiliar de serviço de segurança, encarregado de portaria e segurança, encarregado de segurança, encarregado de vigilância - organizações particulares de segurança, fiscal de segurança, fiscal de vigilância - organizações particulares de segurança, fiscal de vigilância bancária, guarda de banco organizações particulares de segura nça, guarda de cais do porto, guarda de comporta - canais ou portos, guarda de segurança - empresa particular de segurança, guarda de vigilância, guarda ferroviário, guarda portuário, guarda valores, guarda vigia, guarda-civil, guarda-costas, inspetor de vigilância, rondaorganizações particulares de segurança, rondante - organizações particulares de segurança, vigilantebancário

Família Ocupacional 5103 - Supervisores dos serviços de proteção, segurança e outros

- Ocupação 5103-05 - Supervisor de bombeiros : Encarregado de bombeiros, líder de bombeiros

- Ocupação 5103-10 - Supervisor de vigilantes: inspetor de segurança, supervisor de segurança (vigilância), supervisor de segurança patrimonial

Fonte: $\mathrm{CBO} 2.0$

${ }^{13}$ Na CBO 2002 "ocupação" é um conceito sintético construído pelos analistas a partir da agregação de empregos ou situacões de trabalho similares quanto às atividades realizadas. Assim, o conceito não coincide com as atividades exercidas pelo cidadão em um emprego ou outro tipo de relação de trabalho (autônomo, por exemplo).
"Família Ocupacional”, por sua vez, é uma unidade de classificação descritiva mais desagregada. Assim como a ocupação, o grupo de base ou família ocupacional é uma categoria sintética, um construto elaborado a partir de informações reais, mas que não existe objetivamente. 
ção os pré-requisitos individuais necessários ao exercício da profissão de vigilante: idade igual ou superior a 21 anos e escolaridade igual ou superior a $4^{\mathrm{a}}$ série do Ensino Fundamental.

O procedimento descrito acima é satisfatório para mensurar o tamanho e a evolução do segmento especializado na prestação de serviços de segurança privada, que emerge claramente a partir do cruzamento das categorias CNAE e dos códigos da CBO descritos nos Quadros 1 e 2, mas não ajuda muito na mensuração do segmento legal de segurança orgânica. Como esse segmento está organizado junto a empresas que atuam em atividades econômicas variadas, os vigilantes orgânicos somente podem ser identificados nas bases de dados públicas por meio dos códigos da CBO assinalados em cinza no Quadro 2, o que implica grandes distorções. Dados de 2009 sobre o setor de segurança privada da cidade de São Paulo mostram que RAIS e SISVIP possuem números muito díspares em relação ao segmento de segurança orgânica. Como mostra a Tabela 1, há uma diferença aceitável entre RAIS e SISVIP para o caso dos vigilantes ocupados no segmento especializado (vigilantes terceirizados), mas uma diferença grande em relação aos vigilantes orgânicos. Pela RAIS, os orgânicos correspondiam a aproximadamente $30 \%$ do total de vigilantes empregados no setor de segurança privada da cidade de São Paulo, ao passo que, para o SISVIP, eles representavam apenas $6 \%$. Como o interesse do trabalho recai apenas sobre o setor regular de segurança privada, que é autorizado e controlado pela Polícia Federal, optou-se por considerar a fonte policial como a mais fidedigna. Assim, para mensurar a evolução do segmento de segurança orgânica realizou-se uma estimativa numérica com base nas diferenças entre RAIS e SISVIP mostradas na Tabela 1.
Considerando as ressalvas aqui feitas, a análise que segue deve ser lida menos como um diagnóstico preciso das dimensões, evolução e características do setor de segurança privada da RMSP, e mais como um retrato o mais acurado possível desse setor.

\section{O setor de segurança privada da RMSP}

O setor de segurança privada da RMSP é o principal e mais importante mercado local de segurança privada do país. Segundo dados da Polícia Federal, em maio de 2011, a região contava com 299 empresas de segurança privada autorizadas, 614 empresas com segurança orgânica e 15 cursos de formação de vigilantes. Esses números representavam $20 \%$ das empresas de segurança privada e $32 \%$ das empresas com segurança orgânica legalmente constituídas no Brasil. Essa concentração não se repetia no segmento de cursos de formação de vigilantes. Apenas 7\% dos cursos autorizados no Brasil estavam localizados nas cidades da grande São Paulo (ver Tabela 2).

A concentração do setor de segurança privada na RMSP também pode ser constatada em relação ao número de vigilantes regularmente empregados, como mostra a Tabela 2. As informações da Polícia Federal indicam que, em maio de 2011, a grande São Paulo contava com 124 mil vigilantes terceirizados e 08 mil vigilantes orgânicos, que, juntos, totalizavam um efetivo de 132 mil homens. Esse efetivo equivalia a $23 \%$ dos vigilantes brasileiros ocupados em empresas especializadas (vigilantes terceirizados) e $24 \%$ dos vigilantes empregados no segmento de segurança orgânica (vigilantes orgânicos). Os dados da Tabela 2 também mostram que, embora haja mais empresas com segurança orgânica do que empresas de segurança privada, as primeiras empregam apenas uma pequena parte dos vigilantes ocupados na grande São Paulo. O setor legal de segurança privada é dominado pelos vigilantes terceirizados, que 
Tabela 2 - Dimensões do setor de segurança privada - RMSP (maio de 2011)

\begin{tabular}{l|cc|cc}
\hline \multirow{2}{*}{$\begin{array}{c}\text { Tipo de } \\
\text { organização }\end{array}$} & \multicolumn{2}{|c|}{ Número } & \multicolumn{2}{c}{$\begin{array}{c}\text { Participação } \\
\text { no setor nacional - \% }\end{array}$} \\
\cline { 2 - 5 } & Empresas & Vigilantes & Empresas & Vigilantes \\
\hline Especializadas & 299 & 124.063 & 19,96 & 22,98 \\
\hline Orgânicas & 614 & 8.218 & 31,90 & 24,49 \\
\hline Escolas para vigilantes & 15 & - & 7,41 & - \\
\hline
\end{tabular}

Fonte: Construída a partir de dados do SISVIP/DPF e RAIS/MTE

correspondem a $94 \%$ do total de vigilantes que atuam na região. As razões para essa concentração encontram-se nas próprias características dos dois segmentos. Enquanto as empresas de segurança privada são especializadas na comercialização de serviços de segurança, as empresas com segurança orgânica são especializadas em outros ramos de atividade e organizam corpos de segurança (contratam vigilantes) para o seu próprio consumo. Portanto, a concentração de vigilantes no segmento especializado não é algo particular ao setor de segurança privada da RMSP. Onde o segmento especializado na prestação de serviços de segurança privada é desenvolvido, essa concentração tende a ocorrer. Particulares à RMSP são as dimensões que a segurança privada assume, especialmente quando comparada ao setor de segurança pública.

Como ilustra o Gráfico 1, o setor de segurança privada contava com um efetivo maior do que o efetivo das principais organizações de segurança pública que atuavam na RMSP. No primeiro semestre de 2011, o setor de segurança privada ocupava 2,1 vezes mais profissionais de segurança do que

Gráfico 1 - Segurança privada e segurança pública - RMSP (2011)

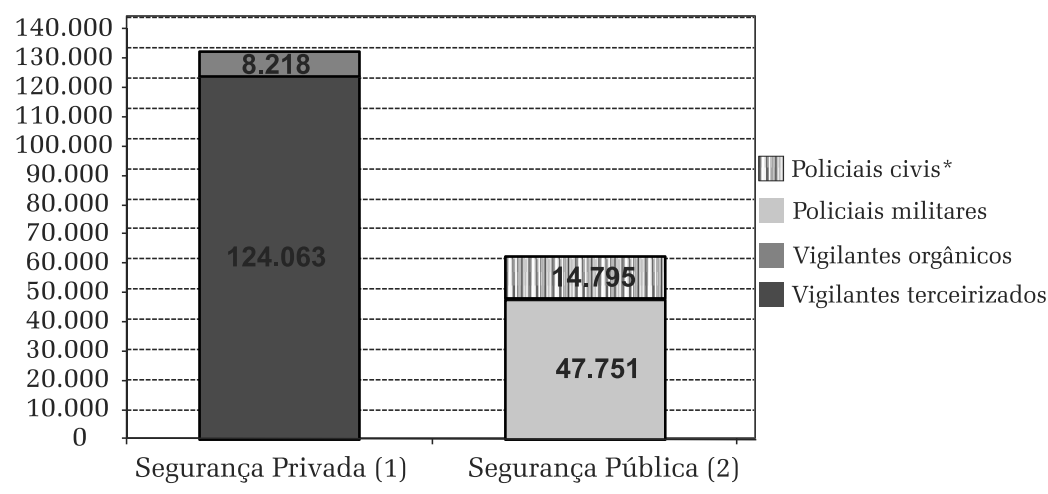

Fonte: Construído pelo autor a partir de: (1) dados do DPF/SISVIP de 05/2011; e (2) dados da CAP/SSP de 02/2011.

* Exclui os policiais lotados na Superintendência da Polícia Técnico-Científica (SPTC) as forças estaduais de segurança pública, que dispunham de $48 \mathrm{mil}$ policiais militares e 15 mil policiais civis. Essa discrepância entre vigilantes e policiais atesta a robustez e a importância que o setor de segurança privada adquiriu dentro da estrutura de policiamento existente na grande São Paulo.

Essa importância foi conquistada paulatinamente ao longo das últimas três décadas. A proliferação dos três tipos de organizações que formam o setor de segurança privada da RMSP ocorreu, em grande medida, durante os anos 80 e 90 . As escolas de formação de vigilantes se constituíram ainda na década de 80. Como mostram os dados da Tabela 3, em 1990, a grande São Paulo já contava com 15 cursos de formação de vigilantes autorizados, número que pouco oscilou durante as décadas seguintes. A formação desse segmento na década de 80 foi um pré-requisito para que a oferta de serviços de segurança no mercado e a constituição de corpos orgânicos no interior de empresas e organizações se expandissem nas décadas seguintes. $\mathrm{O}$ momento mais decisivo dessa expansão foi a década de 90. Durante essa década, as empresas especializadas na prestação de serviços de segurança cresceram em média 13\% ao ano, saltando de 82 em 1990 para $284 \mathrm{em} 2000$ (crescimento acumulado de 246\%). A expansão da oferta de serviços de segurança no mercado continuou a crescer nos anos 2000, mas a taxas anuais muito menores (crescimento médio de 0,96\%). Infelizmente, não há dados disponíveis sobre a expansão do segmento de segurança orgânica durante a década de 90 , mas os dados para o período 2000-2010 mostram um ligeiro crescimento de $3 \%$ (crescimento anual de 0,38\%) dentro desse segmento.

Estatísticas mais recentes do mercado formal de trabalho, registradas pela RAIS/ 
Tabela 3 - Organizaçóes de segurança privada autorizadas - RMSP (1990-2010)

\begin{tabular}{l|c|c|c|c|c|c|c}
\hline \multirow{2}{*}{\begin{tabular}{c}
\multirow{2}{*}{$\begin{array}{c}\text { Tipo de } \\
\text { organização }\end{array}$} \\
\cline { 2 - 8 }
\end{tabular}} & \multicolumn{3}{|c|}{ Ano } & \multicolumn{4}{c}{ Crescimento percentual } \\
\hline Especializadas & 82 & 284 & 291 & 246,34 & 13,10 & 2,46 & 0,96 \\
\hline Orgânicas & - & 598 & 616 & - & - & 3,01 & 0,38 \\
\hline Escolas para vigilantes & 15 & 17 & 15 & 13,33 & 2,78 & $-11,76$ & $-0,47$ \\
\hline
\end{tabular}

Fonte: Construída a partir de dados do SISVIP/DPF, DOU/SESVESP e DOU/Datasafe
Ao que tudo indica, o setor de segurança privada da RMSP superou o setor de segurança pública em termos de efetivo em algum momento da década de 2000. Assim, embora o momento

MTE, também apontam para uma expansão contí- mais decisivo da expansão e consolidação das ornua do setor de segurança privada em relação ao número de vigilantes regularmente empregados (ver Tabela 4). Os números mais conservadores indicam que, em 2007, havia aproximadamente $87 \mathrm{mil}$ vigilantes ocupados no setor de segurança privada. Três anos depois, a quantidade de vigilantes ocupados já ultrapassava os 107 mil homens Essa evolução de $23 \%$ no número de vigilantes ocupados em empresas de segurança privada e com segurança orgânica contrasta com a evolução do setor de segurança pública da RMSP no mesmo período. Segundo dados da Secretaria de Segurança Pública de São Paulo, a quantidade de policiais civis e militares alocados na região manteve-se praticamente a mesma no período 2007-2010. Como resultado, a relação entre vigilantes e policiais, que já era favorável ao setor de segurança privada em 2007 (1,38 vigilantes por policial), aumentou ainda mais em 2010, alcançando 1,70 vigilantes por policial. ${ }^{14}$ ganizações de segurança privada da grande São Paulo tenha sido as décadas de 80 e 90, a virada em direção a uma estrutura de policiamento plural, com o predomínio numérico dos profissionais regulares de segurança privada, ocorreu somente na década seguinte.

Dados sobre os contratantes e organizadores de serviços regulares de segurança privada sugerem que essa pluralização do policiamento ocorreu principalmente sobre o patrocínio do Estado e de propriedades privadas de massa. Segundo dados do Departamento de Polícia Federal, mais da metade (56\%) dos vigilantes orgânicos atuam em propriedades privadas onde trabalham ou moram milhares de pessoas, caso das indústrias e empresas (43\%), condomínios residenciais (11\%) e outros espaços privados tais como sedes de associações beneficentes, profissionais e corporativas (2\%). Os demais vigilantes orgânicos (44\%) estão

Tabela 4 - Evolução do número de vigilantes e policiais - RMSP (2007 a 2010)

\begin{tabular}{|c|c|c|c|c|c|c|}
\hline \multirow{2}{*}{$\begin{array}{c}\text { Tipo de } \\
\text { organização }\end{array}$} & \multicolumn{4}{|c|}{ Ano } & \multicolumn{2}{|c|}{ Crescimento percentual } \\
\hline & 2007 & 2008 & 2009 & 2010 & $2007-2010$ & Média anual \\
\hline Total de vigilantes & 87.090 & 97.488 & 101.198 & 107.037 & 22,90 & 7,17 \\
\hline Vigilantes terceirizados & 82.350 & 92.371 & 95.909 & 101.804 & 23,62 & 7,38 \\
\hline Vigilantes orgânicos* & 4.740 & 5.117 & 5.289 & 5.233 & 10,41 & 3,42 \\
\hline Total de policiais & 63.155 & 62.326 & 61.604 & 63.129 & $-0,04$ & 0,00 \\
\hline Policiais militares & 47.753 & 46.790 & 45.787 & 47.862 & 0,23 & 0,12 \\
\hline Policiais civis** & 15.402 & 15.536 & 15.817 & 15.267 & $-0,88$ & $-0,27$ \\
\hline Taxa de vigilantes por policiais & 1,38 & 1,56 & 1,64 & 1,70 & & \\
\hline Taxa de vigilantes por policiais militares & 1,82 & 1,86 & 1,90 & 1,82 & & \\
\hline Taxa de vigilantes por policiais civis & 5,65 & 5,61 & 5,51 & 5,70 & & \\
\hline \multicolumn{7}{|c|}{$\begin{array}{l}\text { Fonte: RAIS/MTE, SISVIP/DPF e CAP/SSP-SP } \\
{ }^{*} \text { Número estimado com base nas diferenças verificadas entre RAIS/MTE e SISVIP/DPF } \\
\text { * Exclui policiais lotados na Superintendência de Política Técnico-Científica (SPTC) }\end{array}$} \\
\hline
\end{tabular}


alocados em propriedades privadas abertas à mostra o Gráfico 3 , a distribuição do efetivo dessas visitação pública, principalmente estabelecimen- 24 empresas junto aos tomadores de serviços de tos comerciais e shopping centers, que empregam segurança privada (clientes) é bastante diferente da 24\% do total de vigilantes orgânicos da grande São distribuição do efetivo orgânico. Paulo (ver Gráfico 2).

Ao contrário do que ocorre com os orgâni-

Gráfico 2 - Área de atuação dos vigilantes orgânicos - RMSP (2011)

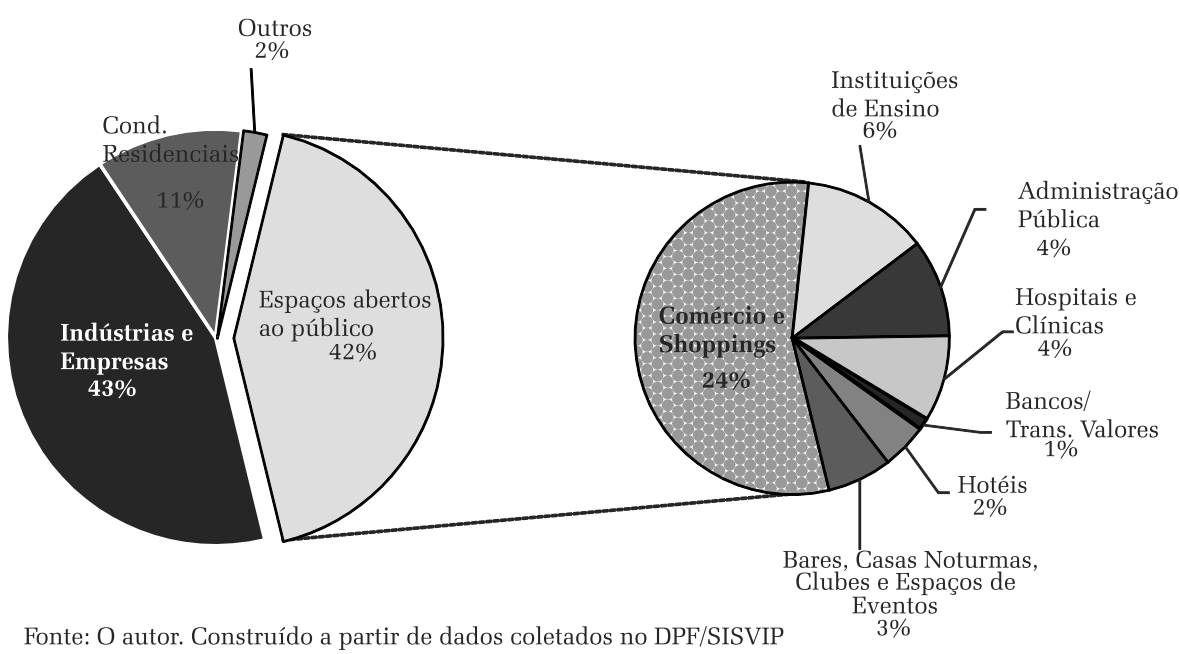

cos, a maioria (60\%) dos terceirizados executa policiamento em espaços localizados no interior de propriedades públicas ou privadas que são abertas ao público e frequentadas pela maioria da população, pois oferecem bens e serviços essenciais. Destaque especial para os espaços da administração
Mas os vigilantes orgânicos correspondem a uma pequena parte do total de vigilantes que integram o setor legal de segurança privada da RMSP. Como foi assinalado anteriormente, cerca de $94 \%$ dos vigilantes da região estão ocupados em empresas de segurança que prestam serviços para terceiros, o que impossibilita a identificação do local de atuação desses profissionais por meio das bases de dados públicas. Por essa razão, dados precisos sobre o local onde os vigilantes terceirizados trabalham são difíceis de obter. A informação mais acurada a esse respeito provém do "I Estudo SESVESP sobre o Segmento Prestador de Serviços de Segurança Privada", que apresenta como um de seus objetivos o de detectar o perfil da demanda por segurança privada no Estado de São Paulo (Lopes, 2012). O estudo contou com a participação de 24 empresas de segurança da grande São Paulo, que, juntas, empregavam cerca de 33 mil vigilantes (26\% do total de vigilantes terceirizados) ${ }^{15}$. Como

15 As empresas que participaram da pesquisa foram selecionadas numa amostragem probabilística proporcional ao tamanho das empresas - sampling with probabilities proportional to size (pps sampling). A amostra era formada por 115 empresas e foi planejada para pública e para as agências bancárias, que respondiam por $29 \%$ e $24 \%$ da demanda por vigilantes terceirizados, respectivamente.

Esses dados sugerem que os moradores da RMSP encontram-se hoje mais expostos às atividades de policiamento executadas por seguranças particulares regulares do que ao policiamento realizado pelas forças estaduais de segurança pública. Se considerarmos as atividades alegais e ilegais de policiamento privado, cujas dimensões ninguém sabe ao certo, esse fato torna-se ainda mais evidente. Essa realidade parece justificar a importância de entendermos o fenômeno do policiamento privado dentro da realidade brasileira. E um bom caminho para isso é incorporar as elaborações teóricas e a agenda de pesquisa dos pesquisadores anglo-saxões que têm se ocupado da temática do policiamento privado há décadas.

obter estatísticas sobre os locais de atuação dos vigilantes ocupados em empresas de segurança privada do estado de São Paulo com um erro amostral de no máximo $5 \%$, com intervalos de confiança de 95\%. Das 115 empresas selecionadas para participar da pesquisa, apenas 29 responderam ao questionário enviado. Dessas, 24 eram empresas cuja principal área de atuação era a Grande São Paulo. Para mais detalhes, ver Lopes (2012, p.7-8). 
Gráfico 3 - Área de atuação dos vigilantes terceirizados - amostra aleatória de 24 empresas que atuam na RMSP (2011)

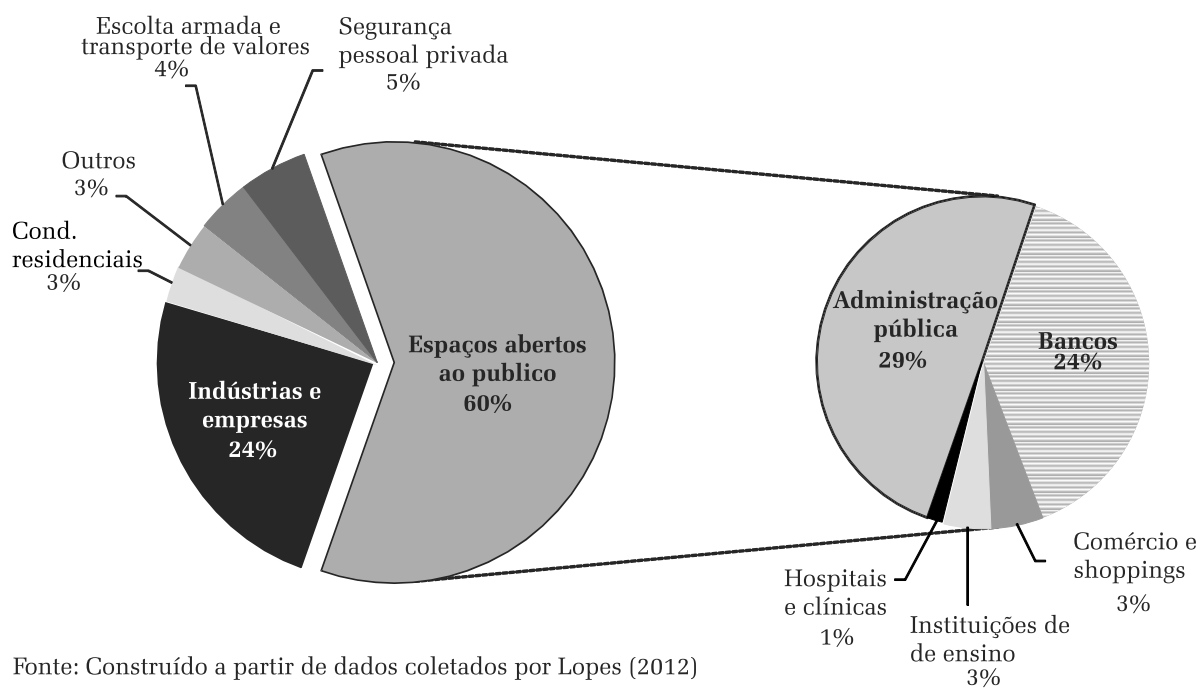

\section{CONSIDERAÇÕES FINAIS}

Esforços promovidos por estudiosos anglosaxões, nas três últimas décadas, propiciaram o surgimento de uma nova linha de investigação sobre as tendências do policiamento no mundo contemporâneo. Essa linha de pesquisa encontra-se consolidada dentro do campo disciplinar dos policing studies. Como notaram Jones e Newburn (2006, p. 1), entre criminólogos e cientistas sociais dos países de língua inglesa tornou-se um lugar comum a observação de que existe muito mais policiamento do que polícia (estatal) nas sociedades contemporâneas. Apesar da pluralização do policiamento também ser uma realidade no Brasil, essa constatação e seus desdobramentos ainda não se impuseram nas ciências sociais brasileiras. De um modo geral, a agenda de pesquisa dos estudiosos tupiniquins ainda não incorporou as perguntas, os conceitos e as evidências contidas na literatura anglo-saxã. Nessas condições, é proveitoso finalizar com uma breve reprodução da agenda de pesquisa proposta há mais de uma década por Bayley e Shearing (2001, p. 35-38) e fazer algumas breves indicações à luz dos dados apresentados anteriormente. Essa agenda é formada por problemas que giram em torno de quatro eixos:

. Descrições básicas - Quem são, quantos são e o que fazem os provedores e patrocinadores de policiamento? Como a polícia tem se adaptado a esse ambiente de policiamento plural? Como provedores estatais e não estatais interagem?

. Causas - Que fatores têm contribuído para o crescimento do policiamento provido por atores não estatais?

O que explica as diferenças regulatórias entre países? O que explica eventuais diferenças entre as mentalidades e práticas de provedores de policiamento?

. Impactos sociais - A pluralização do policiamento tem resultado em mais segurança, e para quem? A distribuição do policiamento público tem passado por mudanças em função da emergência de novos provedores? $\mathrm{O}$ apoio à polícia tem declinado entre os grupos que dispõem de recursos privados de proteção? As atividades de policiamento privado têm resultado em violações de direitos civis? Em que essas violações se distinguem daquelas perpetradas por agentes públicos? Provedores de segurança não estatais são mais controlados do que os provedores públicos?

Política governamental - O que o governo tem feito diante da nova estrutura de policiamento? Que atores e aspectos das atividades de policiamento privado estão submetidos à regulação estatal? Quão efetivo é o controle que o Estado exerce sobre os provedores não estatais sujeitos à regulação pública?

A contribuição deste artigo para o avanço dessa agenda é modesta e concentrada basicamente no primeiro eixo de problemáticas. A tipologia das formas de policiamento discutida anteriormente éfundamental para que a estrutura do policiamento 
existente no Brasil possa ser descrita nos termos da literatura internacional, facilitando, assim, o mapeamento e a identificação das semelhanças e diferenças do caso brasileiro em relação aos demais casos tratados pelos pesquisadores anglo-saxões. Os dados da RMSP sobre os provedores de policiamento indicam, por exemplo, a existência de uma estrutura de policiamento plural, na qual as organizações policiais não são mais hegemônicas em termos de pessoal, conformando uma realidade parecida com a encontrada na América do Norte e na maior parte da Europa ocidental.

Contribuir para o desenvolvimento dos demais eixos da agenda de pesquisa que tem ocupado os pesquisadores anglo-saxões não era o objetivo deste artigo. Entretanto as evidências apresentadas indicam a importância dessa agenda no Brasil e fornecem pistas importantes para pesquisas futuras. Em relação às causas da expansão do setor regular de segurança privada, por exemplo, os dados sugerem que elas devem ser buscadas na década de 90, período que também foi marcado pelo crescimento da criminalidade e do medo do crime, pela incapacidade de a polícia dar uma resposta a esses problemas e pela difusão dos processos de terceirização no setor público e no setor privado, especialmente das atividades de segurança e limpeza. Esses fatores certamente ajudam a explicar o forte crescimento de empresas especializadas na prestação de serviços de segurança privada na grande São Paulo. Todavia é preciso avaliar o peso de outros fatores causais que vêm sendo considerados pela literatura internacional para explicar essa expansão (Van Steden, 2007), dentre os quais:

i. Mudanças nos espaços urbanos - Formação dos espaços para moradia, compras, lazer e serviços que vêm sendo chamados de "propriedades privadas de massa” (Shearing e Stenning, 1981) ou “epaços comunais” (Kempa, Stenning e Wood, 2004), cujas demandas de segurança são demasiadamente heterogênas e complexas para serem atendidas de maneira satisfatória pela polícia.

ii. Racionalidades econômicas - O crescimento da riqueza e do crime gerou incentivos externos e internos para que as organizações utilizassem segurança privada a fim de gerenciar seus riscos e reduzir suas perdas. Os incentivos externos teriam sido fornecidos por três atores: a polícia, que, em alguns locais, retirou-se dos espaços semipúblicos e convenceu os proprietários a se responsabilizarem pela gestão da segurança desses espaços; pelas companhias de seguro, que passaram a oferecer descontos para aqueles que utilizavam segurança privada ou a condicionar coberturas à existência de arranjos de proteção privados; e pelo judiciário, por meio de condenações obrigando os reponsáveis por espaços frequentados pelo público a reparar danos decorrentes de crimes ocorridos em tais espaços. Os gestores de espaços que incentivam a visitação pública também têm motivações intrínsecas para dispor de serviços de segurança privada: reduzir perdas, projetar a imagem de um lugar seguro e atrair clientes.

iii. Políticas governamentais - Incentivo governamental à participaão do setor privado na provisão de policiamento por meio de políticas de cima para baixo (top down privatization) e de baixo para cima (botton up privatization). O primeiro caso seria visível em pelo menos quatro situações: o desinteresse da polícia por tarefas ancilares, como a resposta a alarmes (falsos), que são posteriormente deixadas a cargo da segurança privada; a contratação de agentes privados para desempenhar funções policiais secundárias, como a vigilância de prédios e parques públicos; a cobrança de taxas para que a polícia preste serviços como a segurança em eventos privados com fins lucrativos, algo que induziria os gestores desses eventos a procurar, no mercado, formas mais baratas e alternativas de provisão de segurança; e a promulgação de leis que obrigam determinadas organizações a disporem de serviços de segurança próprios. De baixo para cima, a privatização teria sido influenciada pelo fato de o governo permitir, a polícia incentivar e as comunidades empresariais desejarem participar da gestão da segurança de determinados espaços comerciais abertos ao público. 
iv. Profissionalização da segurança privada - A regulação estatal e a autorregulação existente em muitas jurisdições teriam contribuído para melhorar a imagem dos profissionais de segurança privada, eliminar maus provedores do mercado e garantir a prestação de serviços de acordo com determinados padrões de qualidade, aumentando, assim, a profissionalização do setor e favorecendo sua expansão. Tecnologias de segurança cada vez mais sofisticadas, acessíveis e baratas também teriam contribuído para o fortalecimento e o crescimento da segurança privada.

Os dados apresentados anteriormente também apontam para a necessidade de compreendermos os impactos sociais da expansão do setor de segurança privada sobre a segurança coletiva e sobre os direitos civis da população. Parece certo que a vida dos moradores da RMSP é hoje mais policiada por empresas e profissionais de segurança privada do que pelas forças estaduais de segurança pública. Essa maior exposição dos cidadãos ao policiamento executado pelo setor de segurança privada está relacionada não apenas à superioridade numérica dos vigilantes, mas, sobretudo, ao fato de as pessoas passarem parte substantiva de seu tempo no interior de espaços de moradia, trabalho, compras ou lazer que são policiados privadamente. Dessa forma, o policiamento provido pelas empresas e profissionais de segurança privada, na grande São Paulo, tem impacto direto sobre o cotidiano dos cidadãos. Se esse impacto tem ocorrido no sentido de tornar esse cotidiano mais seguro ou mais suscetível a violações de direitos civis perpetradas por seguranças irresponsáveis, ou a serviço de espaços interessados em ordenamentos sociais que funcionam à revelia da ideia de cidadania são tópicos de grande importância e que deveriam merecer a atenção dos pesquisadores brasileiros.

Recebido para publicação em 11 de julho de 2012 Aceito em 28 de maio de 2013

\section{REFERÊNCIAS}

BAYLEY, D. H. Padrões de policiamento. Uma análise internacional comparativa. São Paulo: EDUSP, 2001.

BAYLEY, D. H.; SHEARING, C. D. The future of policing. Law \& Society Review, Utha,USA, v.30, n.3, p.585-606, 1996

The new structure of policing: description, conceptualization, and research agenda. Relatório de pesquisa. New York: National Institute of Justice (NIJ), 2001.

BICUDO, H. Do esquadrão da morte aos justiceiros. São Paulo: Paulinas, 1988.

BITTNER, E. Aspectos do trabalho policial. Trad. Ana Luísa Amêndola Pinheiro. São Paulo: EDUSP, 2003.

BOBBIO, N. Teoria geral da política: a filosofia política e as lições dos clássicos. Rio de Janeiro: Campus, 2000.

BUTTON, M. Private security and the policing of quasipublic space. International Journal of the Sociology of Law, Philadelphia,USA, v.31, p.227-237, 2003.

CANO, I. Seis por meia dúzia? Um estudo exploratório do fenômeno das chamadas "milícias" no Rio de Janeiro. In: RIBEIRO, C.; DIAS, R.; CARVALHO, S.; SOUZA E SILVA, J.; WILLADINO, R.; LANNES, F.; LEHER, R.; ALVES, J. C. S.; SILVA, I.; ROCHA, L. M.; CANO, I. Segurança, tráfico e milícias. Rio de Janeiro: H. Boll, 2008.

CALDEIRA, T. P. Cidade de muros: crime, segregação e cidadania em São Paulo. 2.ed. Trad. Frank de Oliveira e Henrique Monteiro. São Paulo: Editora 34/EDUSP, 2003.

COHEN, S. Visions of social control. Cambridge: Polity Press, 1985.

COSTA, M. R. Rio de Janeiro e São Paulo nos anos sessenta: a constituição do Esquadrão da Morte. GT21 - Violência, justiça e direitos. In: ENCONTRO DA ANPOCS, 22, 1998. Caxambu, Anais... São Paulo.

DAVIS, R. C.; DADUSH, S.; IRISH, J.; ALVARADO, A. DAVIS, D. The public accountability of private police. Lessons from New York, Johannesburg, and México City. Relatório de Pesquisa. New York: Vera Institute of Justice, 2000. Disponível em http://www.vera.org. Acesso em: 03 mar. 2007

FLORQUIN, N. A Booming business private security and small arms. In: SMALL arms survey 2011. Disponível em: http://www.smallarmssurvey.org/publications/bytype/ yearbook/small-arms-survey-2011.html. Acesso em 03 mar. 2012.

HUGGINS, M. K. Urban violence and police privatization in Brazil: Blended invisibility. Social Justice, [S.l.], Summer, v.27, n.2, p.113-134, 2000.

Violência urbana e privatização do policiamento no Brasil: uma mistura invisível. Caderno $C R H$ : revista do Centro de Recursos Humanos da UFBA, Salvador, v.23, n.60, dez. 2010. Disponível em http://www.scielo.br/ scielo.php?script=sci_arttext\&pid = S $0103-$ $49792010000300007 \& \operatorname{lng}=p \bar{t} \& n r m=$ iso. Acesso em: 14 mar. 2012. Disponível em: http://dx.doi.org/10.1590/ S0103-49792010000300007.

JOHNSTON, L. The rebirth of private policing. London: Routledde, 1992.

Private policing in context. European Journal on Criminal Policy and Research, [S.l.], v. 7, p.175-196, 1999.

JONES, T.; NEWBURN, T. Private security and public policing. Oxford: Clarendon Press, 1998.

The Transformation of Policing? Understanding current trends in policing systems. The British Journal of 
Criminology, Oxford, Academic Research Library, v.42, n.1, p.129-146, dec., 2002.

(Ed). Plural policing: a comparative perspective. Abingdon/New York: Routledge, 2006.

KEMPA, M; CARRIER, R; WOOD, J; SHEARING, C. Reflection of the envolving concept of private policing European Journal on Criminal Policy and Research, [s.l.], ABI/INFORM Global. v.7, n. 7, p. 197-223, 1999.

KEMPA, M.; STENNING, P.; WOOD, J. Policing communal spaces: a reconfiguration of the mass private property hypothesis. The British Journal of Criminology, Oxford, v.44, n.4, p.562-581, 2004.

LOADER, I. Plural policing and democratic governance. Social \& Legal Studies, London, v.9, n.3, p.323-345, 2000.

LOPES, C. S. Como se vigia os vigilantes: o controle da Polícia Federal sobre a segurança privada. 2007. Dissertação (Mestrado em ciência política) - Instituto de Filosofia e Ciências Humanas da Universidade de Campinas. 2007.

. Como se vigia os vigilantes: o controle da Polícia Federal sobre a segurança privada. Revista de Sociologia e Política, Curitiba, v.19, n.40, out. 2011. Disponível em: http:// www.scielo.br/scielo.php?script $=$ sci_arttext\&pid $=$ S0104 44782011000300008\&lng = pt\&nrm $=$ iso. Acesso em: 14 mar. 2012. Diponível em: http://dx.doi.org/10.1590/ S0104-44782011000300008.

I Estudo SESVESP sobre o segmento prestador de serviços de segurança privada, 2012. São Paulo: SESVESP, 2012. Disponível em: http://www.sesvesp.com.br/. Acesso em: 30 maio 2012

MANNING, P. Os estudos sobre a polícia nos países angloamericanos. Caderno CRH: revista do Centro de Recursos Humanos da UFBA, Salvador, v.8, n.45, p.431-446, set./ dez., 2005.

MONET, J. C. Polícias e sociedades na Europa. São Paulo: EDUSP, 2001

MONJARDET, D. O que faz a polícia? São Paulo: EDUSP, 2003.
MISSE, M. "Crime organizado e crime comum no Rio de Janeiro: diferenças e afinidades”. Revista de Sociologia e Politica, Curitiba, v.19, n.40, out. 2011 . Disponível em: http:// www.scielo.br/scielo.php?script $=$ sci arttext\&pid $=$ S0104$44782011000300003 \& \operatorname{lng}=\mathrm{pt} \& \mathrm{nrm}=$ iso. Acesso em: 14 mar. 2012. Disponível em: http://dx.doi.org/10.1590/ S0104-447820 11000300003.

MUIR, Jr., K.W. Police: streetcorner politicians. Chicago: Chicago University Press, 1977.

MUNIZ, J.; PAES-MACHADO, E. "Polícia para quem precisa de polícia: contribuições aos estudos sobre policiamento". Caderno CRH, Salvador, v. 23, n. 60, dez. 2010. Disponível em: http://www.scielo.br/ scielo php?script=sci arttext\&pid=S010349792010000300001\& lng $=\mathrm{pt} \& \mathrm{nrm}=\mathrm{iso}$. acesso em: 14 mar. 2012. Disponível em: http://dx.doi.org/10.1590/ S0103-49792010000300001.

MUIR, Jr., K.W. Police: streetcorner politicians. Chicago: Chicago University Press, 1977.

REINER, R. A Política da polícia. São Paulo: EDUSP, 2004.

SHEARING, C. A relação entre policiamento público e policiamento privado. In: TONRY, M.; MORRIS, N. (Org). Policiamento moderno. São Paulo: EDUSP, 2003.

SHEARING, C.; STENNING, P. Modem private security: its growth and implications. Crime and Justice, [S.l.], v.3, p.193-245, 1981

Private security: implications for control social. Social Problems, [S.1.], v.30, n.5, p.493-506, 1983.

VAN STEDEN, R. Privatizing plicing: describing and explaining the growth of private security. Amsterdam, NE: Legal Publishers, 2007

WEBER, M. Economia e sociedade. Brasília: UnB, 1999.

WOOD, J.; CARDIA, N. Brazil. In: JONES, T; NEWBURN (Ed). Plural policing: a comparative perspective. Abingdon/ New York: Routledge, 2006.

WOOD, J.; DUPONT, B (Ed). Democracy, society and the governance of security. Cambridge: Cambridge University Press, 2006. 


\section{THE PRIVATE SECURITY SECTOR IN THE METROPOLITAN REGION OF SÁO PAULO: growth, dimensions and characteristics}

\section{Cleber da Silva Lopes}

The article mobilizes the expanded concept of policing currently in vogue in the international literature to identify the actors active in the provision of security in Brazil and to analyze empirically the size, growth and some of the characteristics of the legal sector of private security in Metropolitan Region São Paulo. The empirical analysis shows that this sector has experienced a very rapid growth during the decade 90, surpassing the police in terms of personal over the next decade. Most private security operates in workspaces, housing, leisure or shopping where the population spends most of his time. Therefore, the population is more exposed to policing run by private security guards than policing run by police. These facts are discussed in light of a research agenda that has not yet been established in the Brazilian social science.

KEY Words: Social control. Policing. Police. Private security. Metropolitan Region of São Paulo.

\section{LE SECTEUR DE LA SÉCURITÉ PRIVÉE DANS LA RÉGION MÉTROPOLITAINE DE SÃO PAU- LO: croissance, dimensions et caractéristiques}

\author{
Cleber da Silva Lopes
}

L'article mobilise le concept élargi de police actuellement en vogue dans la littérature internationale pour identifier les acteurs actifs dans la fourniture de la sécurité au Brésil et d'analyser empiriquement la taille, la croissance et quelquesunes des caractéristiques du secteur juridique effectuent police sécurité privée dans la région métropolitaine São Paulo. L’analyse empirique montre que ce secteur a connu une croissance très rapide au cours de la décennie 90, dépassant les forces de sécurité en termes d'efficacité durant la prochaine décennie. Sécurité privée plus opère dans des espaces de travail, de logement, de loisirs ou de shopping où la population passe la plupart de son temps et est donc plus exposée aux services de police dirigée par des gardes de sécurité privés de maintien de l'ordre fait par la police. Ces faits sont discutés à la lumière d'un programme de recherche qui n'a pas encore été mis en place dans le domaine des sciences sociales au Brésil

MotS-CLÉs: Contrôle social. Maintien de l'ordre. Police. Sécurité privée. Région Métropolitaine de São Paulo.

Cleber da Silva Lopes - Doutor em Ciência Política. Professor do Departamento de Ciências Sociais e do Mestrado em Ciências Sociais da Universidade Estadual de Londrina. Mestre em Ciência Política pela Universidade de Campinas. Temas de interesse: Organizações de Policiamento (públicas e privadas), Políticas de Segurança Pública, Instituições Políticas e Opinião Pública. Publicações recentes: As tensões entre segurança e direitos civis nos EUA pós-11 de setembro. BIB. Revista Brasileira de Informação Bibliográfica em Ciências Sociais, v. 70, p. 97-120, 2012; Segurança privada e infraestrutura crítica: desafios para a governança da segurança doméstica dos EUA pós 11 de setembro. Revista Mediações (UEL), v. 16, p. 158-176, 2012; Como se vigia os vigilantes: o controle da Polícia Federal sobre a segurança privada. Revista de Sociologia e Política (UFPR. Impresso), v. 19, p. 99-121, 2011. 
